\title{
First Year Chemistry Laboratory Courses for Distance Learners : Development and Transfer Credit Acceptance
}
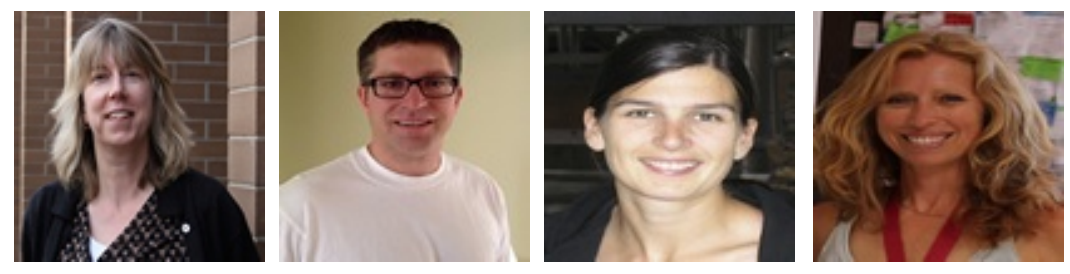

Sharon E. Brewer, Bruno Cinel, Michelle Harrison, and Christina L. Mohr Thompson Rivers University, Canada

\section{Abstract}

In delivering chemistry courses by distance, a key challenge is to offer the learner an authentic and meaningful laboratory experience that still provides the rigour required to continue on in science. To satisfy this need, two distance general chemistry laboratory courses appropriate for Bachelor of Science (B.Sc.) students, including chemistry majors, have been recently developed at Thompson Rivers University. A constructive alignment process was employed which clearly mapped learning outcomes and activities to appropriate assessment tools. These blended laboratory courses feature custom home experimental kits and combine elements of online and hands-on learning. The courses were designed for flexible continuous enrollment and provide online resources including tutor support, instructional videos, lab report submission, and student evaluation. The assessment of students includes laboratory reports, safety quizzes, reflective journaling, digital photo documentation, and invigilated written and online practical exams. Emphasizing the quality and rigour in these distance laboratory learning experiences allowed both courses to be accepted for B.Sc. transfer credit by other institutions, an important criterion for students. This paper will outline the design and development process of these new blended laboratory courses, their course structures and assessments, and initial student results.

Keywords: First year; general chemistry; laboratory; distance education; blended; hands-on; home experimental kits; online; learning outcomes; instructional design; transfer credit 


\section{Introduction}

There is general agreement on the fundamental role of the laboratory component in any first year general chemistry course in a Bachelor of Science program. The exact form or nature of the laboratory experience, however, has been the subject of much debate in the literature (Bennett, Seery, \& Sovegjarto-Wigbers, 2009; Buntine et al., 2007; Domin, 1999; Elliott, Stewart, \& Lagowski, 2008; Pickering, 1993; Reid \& Shah, 2007; Talanquer, 2012). Reid and Shah (2007) presented a general set of goals that chemistry laboratory experiences should include, such as making chemistry real to the student, allowing the student to learn practical and scientific skills, and developing general skills such as problem solving ability. When a general chemistry course is being delivered to a distance student, a key question is how to provide this student with the laboratory portion of the course to accomplish the desired learning objectives.

Many educational institutions have tackled this problem by requiring distance students to attend on-campus laboratory courses offered on weekends or in a multi-day block (Lyall \& Patti, 2010). Expecting a distance student to attend a physical lab course during a narrow and intensive time-frame eliminates the main advantage of distance education, namely flexibility. Another solution is offering distance chemistry students the opportunity to complete the laboratory component of the course from home using home experiment kits. Several academic institutions have adopted this approach by successfully developing and offering these laboratory experiences for their distance general chemistry students in B.Sc. programs (Casanova, Civelli, Kimbrough, Heath, \& Reeves, 2006; Jeshofnig \& J eshofnig, 2011; Kennepohl, 2007; Lyall \& Patti, 2010). Removing students from the "traditional" laboratory setting typically found in our postsecondary institutions does raise questions around how authentic and rigorous the home laboratory learning experience is, especially to other institutions asked to accept these experiences as equivalent for transfer credit. Accordingly, several authors have reported a general resistance in chemistry to accepting non-traditional experiences or alternate delivery modes as being equal to the traditional forms of laboratories (Bradley, Durbach, Bell, Mungarulire, \& Kimel, 1998; Casanova et al., 2006; Forinash \& Wisman, 2001; Reeves \& Kimbrough, 2004).

The Open Learning division of Thompson Rivers University (TRU) had offered distance general chemistry laboratories as separate courses requiring students to attend intensive, one week, on-campus sessions since the early 1980s. This requirement of travelling to the Kamloops campus of TRU to complete the traditional, face-to-face lab experiences presented financial and scheduling barriers for students, particularly those students typically enrolled in distance courses who often work full-time, have a variety of other time commitments, and do not live in the area (thus incurring additional travel and accommodation costs). Removing these barriers by offering true distance versions of the laboratory courses would provide greater flexibility and accessibility to our learners. This approach would involve developing lab courses that combine home experiment kits with online instruction and assessment. The ultimate goal was to 
capitalize on the flexibility and accessibility of online distance education while still providing authentic and rigorous, hands-on laboratory learning experiences. This paper will outline the design and development process of these new blended laboratory courses, their course structures and assessments, and initial student results.

\section{Background and Context of the Blended. Distance Laboratory}

The current literature does not present one common definition of distance education or of online education that is subscribed to by all (Benson, 2004; Moore, Dickson-Deane, \& Galyen, 2011). Because of the lack of consistency in terminology used to describe courses with different delivery modes, it is crucial to provide a clear statement and description of the course context in order to understand its purpose and allow for research comparisons (Moore et al., 2011). In fact, our study combines elements of distance, online, and hands-on learning and, as such, requires a brief discussion and background on the various terms used to set proper framework and context of our course development.

Historically, distance education was defined as all levels of study by students not under direct and continuous instructor or tutor supervision (Holmberg, 1989), and currently refers to education where the student and instructor are physically separated by a geographical distance (Moore et al., 2011). Schlosser and Simonson (2010) define the term more specifically by stating that, along with the separation of instructor/ tutor and student, true distance education must be offered by an educational institution, must have interactive communication between the student and instructor, and must share the results of learning experiences with the student. Advances in technology have allowed distance education to evolve from a traditional correspondence model to one that incorporates online learning into the course itself (Harasim, 2011; Karadeniz, 2009). Subsequently, many recent definitions of distance education found in the literature reflect the learning environment and the impact of technology (Moore et al., 2011).

Online learning is considered to be the younger form of distance learning that grew from remarkable advances in technology (Downing \& Holtz, 2008). It has been described as using web-based delivery and software to provide a structured learning environment (Watson, Murin, Vashaw, Gemin, \& Rapp, 2012) and where the Internet, or a computer network, serves as the primary environment for course interaction and discussion in an online course (Harasim, 2000). The key feature of these definitions is accessing the Internet for educational purposes.

The term e-learning is also found in the literature although there are many different opinions on what it means (Coryell \& Chlup, 2007; Larreamendy-J oerns \& Leinhardt, 2006; Moore et al., 2011; Oblinger \& Hawkins, 2005). A recent study aimed at generating a definition of e-learning that would be acceptable to the majority of the scientific community published the following: 
E-learning is an approach to teaching and learning, representing all or part of the educational model applied, that is based on the use of electronic media and devices as tools for improving access to training, communication and interaction and that facilitates the adoption of new ways of understanding and developing learning. (Sangrà, Vlachopoulos, \& Cabrera, 2012, p. 152)

While often used interchangeably in the literature, Downing and Holtz (2008) remind us that e-learning and distance education terms are not interchangeable even though distance education now typically involves e-learning. Likewise, since e-learning involves technology but does not have to include use of the Internet (Sangrà et al., 2012), online learning is considered a subset of e-learning in accordance with the description of educational context provided by Downing and Holtz (2008).

Blended learning is another term used to describe course environments and has been described in a multitude of ways, yet it currently lacks a generally adopted definition. Blended instruction has been defined as an appropriate mix of face-to-face instruction with learning technologies to support learning and foster achievement of learning outcomes (Lim \& Morris, 2009), as a combination of different delivery methods and styles of learning ( $\mathrm{Wu}$, Tennyson, \& Hsia, 2010), and as a combination of traditional face-to-face learning with online learning activities in authentic combinations that further facilitate student understanding (Macaulay, Van Damme, \& Walker, 2009). Blended courses have also been recognized as a type of online course (Mayadas, Bourne, $\&$ Bacsich, 2009) when they contain online components. Since 2004, the SloanConsortium has organized conferences and workshops focused on blended learning and from these adopted a definition of blended learning that includes courses that have planned integration of online learning with face-to-face activities in a pedagogically sound manner, and courses that have some portion of face-to-face learning defined by an institution being replaced by online activity (Picciano \& Dziuban, 2007). More recent articles focused on blended learning in chemistry describe blended as the combination of face-to-face teaching with online instruction and feedback (Brouwer \& McDonnell, 2009; Williams, Bland, \& Christie, 2008) or with online modules prepared for specific topics (Busstra, Hulshof, Houwen, Elburg, \& Hollman, 2012). Osguthorpe and Graham (2003) point out that when creating a blended learning opportunity, it is important to capture the strengths of the learning environments being combined, and leave out the weaknesses. Often a blended learning experience is attractive pedagogically when it combines some of the advantages of face-to-face teaching with the flexibility of online instruction and access (Williams et al., 2008). The definition of blended learning we favour is learning facilitated by the effective combination of different delivery modes, teaching models, and styles of learning put forth by Heinze, Procter, and Scott (2007). 
The fundamental question emerges of how to effectively blend the required course learning characteristics into an authentic laboratory educational experience by distance. In a traditional lecture format, a key interaction that occurs exists between the instructor and the student. In a laboratory setting, we argue the key advantage of the "face-to-face" experience is the opportunity to have direct, hands-on interaction with the chemicals, apparatus, and instrumentation of a real experiment. This direct "student-experiment" interaction is the whole objective of the laboratory learning experience. Laboratory experiences that feature real equipment needed to perform the experiment physically set up in the same physical location as the experimenter are characterized as hands-on labs (Ma \& Nickerson, 2006). The main attribute of having students physically present with the real lab equipment in a real investigative process distinguishes hands-on labs from other types of laboratory experiences, such as simulated (virtual) labs or remote labs (Ma \& Nickerson, 2006).

Bringing a hands-on experience directly to a distance learner's home can involve the use of kitchen chemistry experiments or home experimental kits. Kitchen chemistry is described in the literature as experiments done at home using commonly available household materials and equipment; however, these experiences are not considered adequate for a general chemistry course and those students considering a career in chemistry-related disciplines (Lyall \& Patti, 2010). Some variations of kitchen chemistry labs where minimal equipment (such as thermometers or $\mathrm{pH}$ paper) is provided have been developed for distance, non-chemistry major students (Boschmann, 2003; Jackson, 1998). In contrast, a home experimental kit uses actual laboratory chemicals, apparatus, and experiments similar to those in a traditional university general chemistry lab setting (Lyall \& Patti, 2010). Laboratories using home experimental kits with procedures delivered to the student via the Internet have been termed hands-on distance labs (Downing \& Holtz, 2008). In a discussion of practical work in online science, Downing and Holtz (2008) describe the use of home laboratory kits for introductory science courses, such as general chemistry, as an appropriate and viable instructional strategy. Many institutions have incorporated this approach in their chemistry course offerings including Athabasca University (Kennepohl, 2007; Lyall \& Patti, 2010), Monash University (Lyall \& Patti, 2010), and Cape Fear Community College (Casanova et al., 2006; Reeves \& Kimbrough, 2004).

Our goal for this project was to use the successful strategies reported in the literature to develop two new blended, distance laboratory courses using hands-on, home experimental kits and online instruction and assessments. These blended chemistry laboratory courses would involve mixed modes of delivery including online course management and assessment, simulated (virtual) experiments, direct, hands-on experimentation, and remote laboratory opportunities. It was imperative that these courses satisfy TRU's first year B.Sc. program requirements for general chemistry laboratories and meet specific standards for transfer of credit to other institutions. In addition, the courses would need to meet the challenges of acceptance that arise when traditional courses are offered via alternate modes of delivery. This recognition helped 
define our collaborative process and emphasized the need for clearly defining our learning outcomes and aligning them to a rigorous assessment scheme.

\section{Method of Course Development}

In 2005, provincial legislation creating Thompson Rivers University from the University College of the Cariboo and the British Columbia Open University stated the new institution must serve the open learning needs of the province (Thompson Rivers University Act, 2005). Up to this point, students could enroll in either the traditional, on-campus chemistry lecture/laboratory courses or the print-based chemistry lecture courses offered by distance. The only opportunity for distance students to engage in chemistry laboratory courses was by physically travelling to campus and participating in intensive, one week, on-campus laboratory courses. These limited yearly offerings, together with the associated time and travel costs, did not match well with our new open and accessible educational mandate. In addition, condensing an entire laboratory course in a short time period has been shown to cause confusion on the part of the student (Lyall \& Patti, 2010).

To address these concerns, we began a process of creating two new first year general chemistry laboratory courses designed to meet the needs of distance learners and satisfy provincial articulation requirements for credit and transferability. These courses would run as self-paced, hands-on, home laboratory experiments offering continuous, year round enrolment, with online resources, tutor support, submission, and evaluation. The courses would allow for a flexible learning experience in both time and place, two features recognized as advantageous to distance students (Al-Shamali \& Connors, 2012; Mawn, Carrico, Charuk, Stote, \& Lawrence, 2011), with students performing experiments according to their preferred schedule and location.

\section{Instructional Design Process}

In developing our distance chemistry laboratory courses, we employed a backward design process (Wiggins \& McTighe, 2005) or results-focused approach that first established the learning outcomes desired for the course, then mapped these outcomes to clearly-defined assessment tools, and finally developed appropriate laboratory experiments to achieve these outcomes. MacLean and Scott (2011) identify that this process of creating constructive alignment (as per Biggs, 2003) by mapping outcomes to activities and assessments increases the likelihood that the resulting learning materials and learning experiences will achieve the desired outcomes for a particular learning event. This process has been recognized as key to encouraging deeper learning (Bennett et al., 2009). Our list of laboratory learning outcomes for each distance course was generated by examining our traditional, on-campus, general chemistry lab courses and constructing an overall set of learning outcomes (some examples are shown in Table 1). From this list, a variety of evaluation and assessment tools were identified to measure student learning. The learning outcomes and assessment tools provided a solid 
framework from which to develop new laboratory experiments or select suitable existing experiments and adapt them to address our educational goals and needs.

Table 1

Example Learning Outcomes and Assessments for Selected Experiments in the New Laboratory Courses

\section{Learning \\ outcome \\ ("The student \\ should be able to \\ satisfactorily ...")}

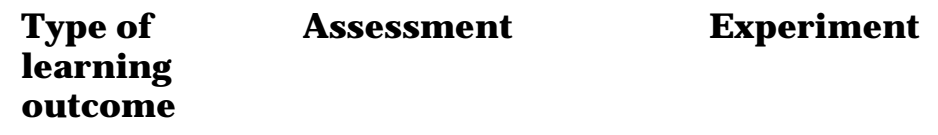

Assessment

Experiment

Create a series of Psychomotor/

dilute solutions from

a stock solution

Operate a simple colorimeter with a multimeter display

Perform a titration using a $\mathrm{pH}$ indicator within the precision limits of the apparatus

Tabulate titration data and use the data to calculate the concentration of an unknown solution

Interpret experimental results and form conclusions

cognitive

Psychomotor

Psychomotor

Cognitive affective
Submit a photo of the titration clearly showing the phenolphthalein end point

$$
\begin{aligned}
& \text { Use data to calculate } \\
& \text { the concentration of } \\
& \text { calcium carbonate in a } \\
& \text { water sample }
\end{aligned}
$$

Beer's Law and Colorimetry successful creation of a dilution series

Submit a photo of the multimeter display showing the resistance

Analysis of Phosphate in Water (and lab exam)

Titration for Acetic Acid in Vinegar

(and lab exam)

Determination of Water Hardness

(and lab exam)

Metacognitive/

Reflectivejournal entry summarizing the learning experience, relating the experiment to its objectives, and highlighting challenges and successes
All experiments (and lab exam)

At this point in the process, a decision was required on whether to develop our own home experimental kits containing all the chemicals, glassware, and materials necessary to perform the course lab experiments (as others have done, see Lyall \& Patti, 2010) or to work with a commercial kit manufacturer. We began by evaluating the strengths and 
weaknesses of many commercially available kits and experiments, with an eye on finding those that best fit our open learning philosophy, learning outcomes, and pedagogy. Although we entered into this evaluation stage with a healthy dose of skepticism about the quality and rigour of these commercial products, we were ultimately suitably impressed by the learning opportunities these kits could provide. After this review of available kits and suppliers, a decision was made to work with Hands-On Labs, Inc., producers of LabPaq ${ }^{\circledR}$ kits for a variety of disciplines and learners (J eschofnig \&J eschofnig, 2011).

The entire catalogue of Labpaq ${ }^{\circledR}$ experiments was investigated and those most suitable for general chemistry laboratories in a first year science program were selected for further evaluation. This iterative process involved testing each experiment from a student's perspective, making recommendations for improvements, and then reassessing whether the experiments could meet our desired list of learning outcomes. The end result was a list of experiments suitable for the two new one-semester laboratory courses (see Table 2).

Table 2

List of Experiments Included in the New Laboratory Courses

\begin{tabular}{ll}
\hline Course & Experiments \\
\hline CHEM 1505: Chemistry Laboratory I & 1 - Observation of Chemical Changes and \\
& Separation of a Mixture of Solids \\
2 - Laboratory Techniques and Measurements & 3 - Liquids and Solids \\
4 - Determination of Water Hardness & 5 - Beer's Law and Colorimetry \\
& 6 - Analysis of Phosphate in Water \\
& 7- Stereochemistry and the Hydrolysis of \\
& Acetylsalicylic Acid \\
CHEM 1525: Chemistry Laboratory II & 1- Qualitative Anion Tests and Identification \\
& of Cations \\
2 - Properties of Gases \\
3 - Caloric Content of Food \\
4- Le Châtelier's Principle \\
5 - Reaction Order and Rate Laws \\
6- Titration for Acetic Acid in Vinegar \\
7- Determination of Ka for a Weak Acid \\
8 - Using Buffers \\
9- Oxidation-Reduction/ Activity Series \\
10 - Electrochemical Cells and Cell Potentials \\
\hline
\end{tabular}


Each experiment was then subjected to rigorous and repeated testing and modification by chemistry faculty and students. Specific learning outcomes, including those focused on both the cognitive and psychomotor learning domains, were assigned and tied directly to assessments. New laboratory manuals were created for each course to provide sound pedagogical structure for student learning and to suit our desired learning goals and teaching philosophy. Hands-On Labs Inc. was very amenable to this process and worked together with us to incorporate the modifications into the experiments and manuals. Final student testing and revisions were conducted on prototype Labpaq ${ }^{\circledR}$ home experimental kits incorporating the new laboratory manuals.

Once the new course laboratory kits and manuals were finalized, online multimedia resources, including videos and photographs, were developed to aid the distance learner (see Table 3). These resources demonstrated and emphasized proper safety procedures, laboratory techniques, and equipment assembly and were accessed through the online course management systems developed for each laboratory course. We considered the development and inclusion of these multimedia resources to be mandatory for our lab courses since both photographs and instructional videos are important for student distance learning.

Table 3

List of Instructional Videos Developed for the New Laboratory Courses

\begin{tabular}{ll}
\hline Course & Videos \\
\hline CHEM 1505: Chemistry Laboratory I & Introductions \\
& Dispensing Chemicals \\
& Dropping Chemicals \\
& Heating Chemicals \\
& Proper Use of Pipet \\
Test Tube Assembly & Titrator Assembly \\
Colorimeter Set-Up & Model Kit \\
& Volumetric Flask \\
& Balance \\
& Filter Folding and Ice Water Bath \\
& Dispensing Chemicals \\
CHEM 1525: Chemistry Laboratory II & Dropping Chemicals \\
& Heating Chemicals \\
& Proper Use of Pipet \\
Titrator Assembly \\
Volumetric Flask \\
Balance \\
Filter Folding and Ice Water Bath \\
Using Indicators \\
Gas Collection \\
Flame Test \\
Electrochemical Cell \\
\hline
\end{tabular}




\section{Student Assessment}

From the learning outcomes identified for the new distance laboratory courses, a formative assessment scheme was developed for each lab experiment as well as an overall summative evaluation to ensure rigour and transfer credits at other postsecondary institutions. Students were provided with a comprehensive assessment package linked to the course management system detailing the expectations, valuations, timelines, and instructions for student assessment. Each laboratory course included a safety quiz, online laboratory journals, written laboratory reports, and invigilated written and practical final lab exams (see Table 4).

Table 4

Assessment Tools and Valuations for the New Laboratory Courses

\begin{tabular}{ll}
\hline Assessment tool & $\begin{array}{l}\text { Percentage of } \\
\text { final mark }\end{array}$ \\
\hline Safety quiz & $5 \%$ \\
Online laboratory journal & $25 \%$ \\
Laboratory reports & $40 \%$ \\
Final lab exams & $30 \%$ \\
Total & $100 \%$ \\
\hline
\end{tabular}

At the beginning of each course, students are expected to sign a safety checklist and also complete and pass an online safety quiz that emphasizes the awareness of potential hazards and proper chemistry laboratory conduct. The quiz is written prior to performing any experiments and may be attempted more than once; however, the student's grade for this assessment reflects the average of all the attempts. The online laboratory journal includes features which allow students to demonstrate their abilities in completing the experiments using proper techniques and skills, and also document their metacognitive learning process. The journal postings include uploading photos and associated descriptions of their equipment set-up, experimental observations, or laboratory results. Figure 1 shows actual student photographs of experimental results used later by the course instructor to qualitatively assess lab performance and compare to quantitative data. (For example, Figure la clearly shows the expected increase in colour associated with increasing concentration; whereas, the deep pink colour in Figure $1 \mathrm{~b}$ suggests the student overshot the phenophthalein endpoint of the titration.) Students are also evaluated on their response to a reflective question about what was learned over the course of each experiment (see Table 5). As a whole, the online laboratory journal entries are designed to encourage students to reflect on their learning and understanding of the experiments, to document their learning process, and to 
highlight any challenges or successes. Each experiment also requires online submission of a laboratory report including any associated data or observations, results, graphs, calculations, summaries, or answers to questions that may be required.

a)

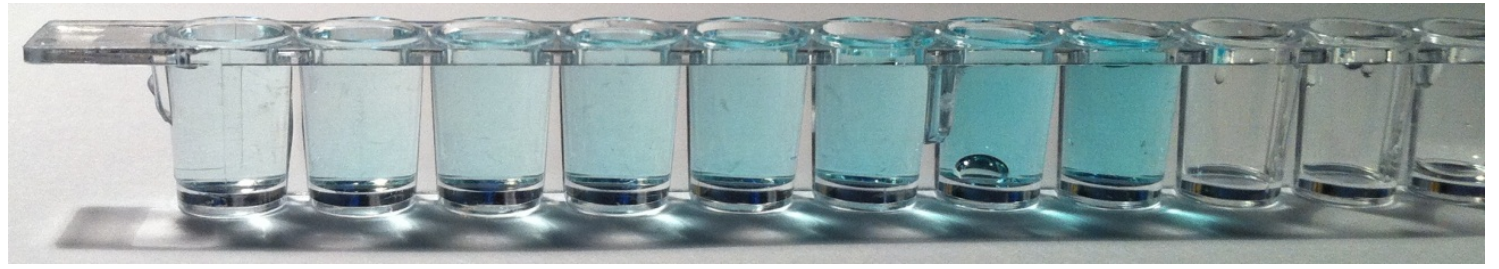

b)



Figure 1. Student photographs showing a) a series of dilutions and b) the results of a titration. 
Table 5

Rubric for Evaluating Reflective Learning J ournal Questions

\begin{tabular}{lll}
\hline Excellent (4-5 marks) & $\begin{array}{l}\text { Satisfactory (2.5-4 } \\
\text { marks) }\end{array}$ & $\begin{array}{l}\text { Minimal (0-2.5 } \\
\text { marks) }\end{array}$ \\
\hline $\begin{array}{l}\text { Evidence of experimental } \\
\text { observations leading to } \\
\text { concepts learned in } \\
\text { experiment }\end{array}$ & $\begin{array}{l}\text { Some evidence of } \\
\text { experimental observations } \\
\text { leading to concepts learned } \\
\text { in experiment }\end{array}$ & $\begin{array}{l}\text { Minimal evidence of } \\
\text { experimental } \\
\text { observations leading to } \\
\text { concepts learned in } \\
\text { experiment }\end{array}$ \\
$\begin{array}{l}\text { Clearly summarized what } \\
\text { was learned in the }\end{array}$ & $\begin{array}{l}\text { Summarized what was } \\
\text { learned in the experiment, } \\
\text { but may have missed some } \\
\text { key points }\end{array}$ & $\begin{array}{l}\text { Learning not } \\
\text { summarized }\end{array}$ \\
$\begin{array}{l}\text { Overall conclusions well- } \\
\text { formulated }\end{array}$ & $\begin{array}{l}\text { Conclusions formulated, but } \\
\text { may have missed some } \\
\text { points }\end{array}$ & $\begin{array}{l}\text { Conclusions not } \\
\text { formulated }\end{array}$ \\
$\begin{array}{l}\text { Clear links/relation between } \\
\text { observations in the } \\
\text { experiment and } \\
\text { experimental theory }\end{array}$ & $\begin{array}{l}\text { Some links/relation between } \\
\text { observations in the } \\
\text { experiment and } \\
\text { experimental theory }\end{array}$ & $\begin{array}{l}\text { Minimal links/relation } \\
\text { between observations in } \\
\text { the experiment and } \\
\text { experimental theory }\end{array}$ \\
$\begin{array}{l}\text { Demonstrated self-reflective } \\
\text { learning by clearly outlining } \\
\text { an experimental challenge } \\
\text { and/ or an experimental } \\
\text { success }\end{array}$ & $\begin{array}{l}\text { Demonstrated self-reflective } \\
\text { learning by mentioning an } \\
\text { experimental challenge } \\
\text { and/ or an experimental } \\
\text { success }\end{array}$ & $\begin{array}{l}\text { No self-reflective } \\
\text { learning demonstrated }\end{array}$ \\
\hline
\end{tabular}

The final summative evaluation component consists of invigilated (proctored) written and practical laboratory exams. These may either be supervised in-person at a predetermined examination location or by live-streaming video over the Internet. The written component examines knowledge and application of the techniques and calculations encountered throughout each laboratory course. The practical final exam involves performing a complete experiment to demonstrate proficient laboratory techniques and skills. Students are asked to open an examination package containing a previous experiment they performed in the lab and repeat the experiment on a new, unknown sample. The tutor evaluation may be done via a live video streaming session or an invigilated video recording submission. This intensive and comprehensive assessment of a student's laboratory techniques and skills fulfills a key requirement of each distance laboratory course and ensures quality and rigour for transfer credit 
purposes. An aggregate percentage of at least 50\% must be achieved on the sum of the lab reports and the two, equally weighted final exams in order to receive a passing grade for each course.

\section{Outcomes}

The laboratory courses were fully developed and open for student enrolment in 2009. Thompson Rivers University anticipates enrolment numbers, orders the home experimental kits from Hands-On Labs Inc., stores these kits at the TRU distribution warehouse, and then ships them to students upon registration. All student support, including dealing with missing or broken kit items, is provided by TRU and students have no interaction with the kit vendor. Our microscale experiments involve very small amounts of chemicals and there have been no problems shipping these laboratory kits outside our province of BC. As part of the distance lab course enrolment process, students are assigned a tutor as their key contact for questions and course assessment, including grading lab reports and invigilated final exams.

Enrolments into the newly developed, home distance laboratory courses began in 2009 with the first student completions and grades assigned early in 2010. In the two years prior to implementing these new courses, a total of 28 students completed the weeklong, intensive, on-campus laboratory offerings. The first two years of the home experimental kits and online blended versions of these laboratories saw a jump in student enrolments and, overall, a total of 44 final grades were assigned to students originating from TRU and other academic institutions. The number of course registrants and completions continues to grow, perhaps in part due to meeting student scheduling and location needs by increasing flexibility and access.

In comparing the final mark distributions between the two laboratory course delivery methods, there are two noticeable features that appear (see Figure 2). First, we have traditionally seen fairly high achievements in our distance laboratories, irrespective of mode of delivery. This may be attributed to the fact that, originally, students were participating in a week-long, intensive laboratory experience which probably comprised their only scheduled course or activity. Thus, these students were free to devote considerable time and attention to the academics of the course and were very committed, having travelled extensively, in some cases, to participate. Similarly, a vast majority of our students enrolled in the new, blended, distance laboratory courses are most likely participating in part-time academic studies (compared to their traditional, face-to-face colleagues) (TRU Institutional Planning and Analysis, 2012) and can devote more of themselves to the course. In addition, the flexibility afforded the students to complete the course requirements and submit reports and assignments may play a role. The second notable feature from Figure 2 is the increased percentage of students not completing or failing the courses. This is consistent with what others have seen in distance education (Carr, 2000; Howell, Laws, \& Lindsay, 2004) and likely reflects the increased student discipline and independence required to remain on track and focused 
on their course progression and learning, especially in comparison to the traditional, face-to-face, and cohort delivery models. Overall, the student mark distributions to date are consistent with our expectations and will continue to be tracked.

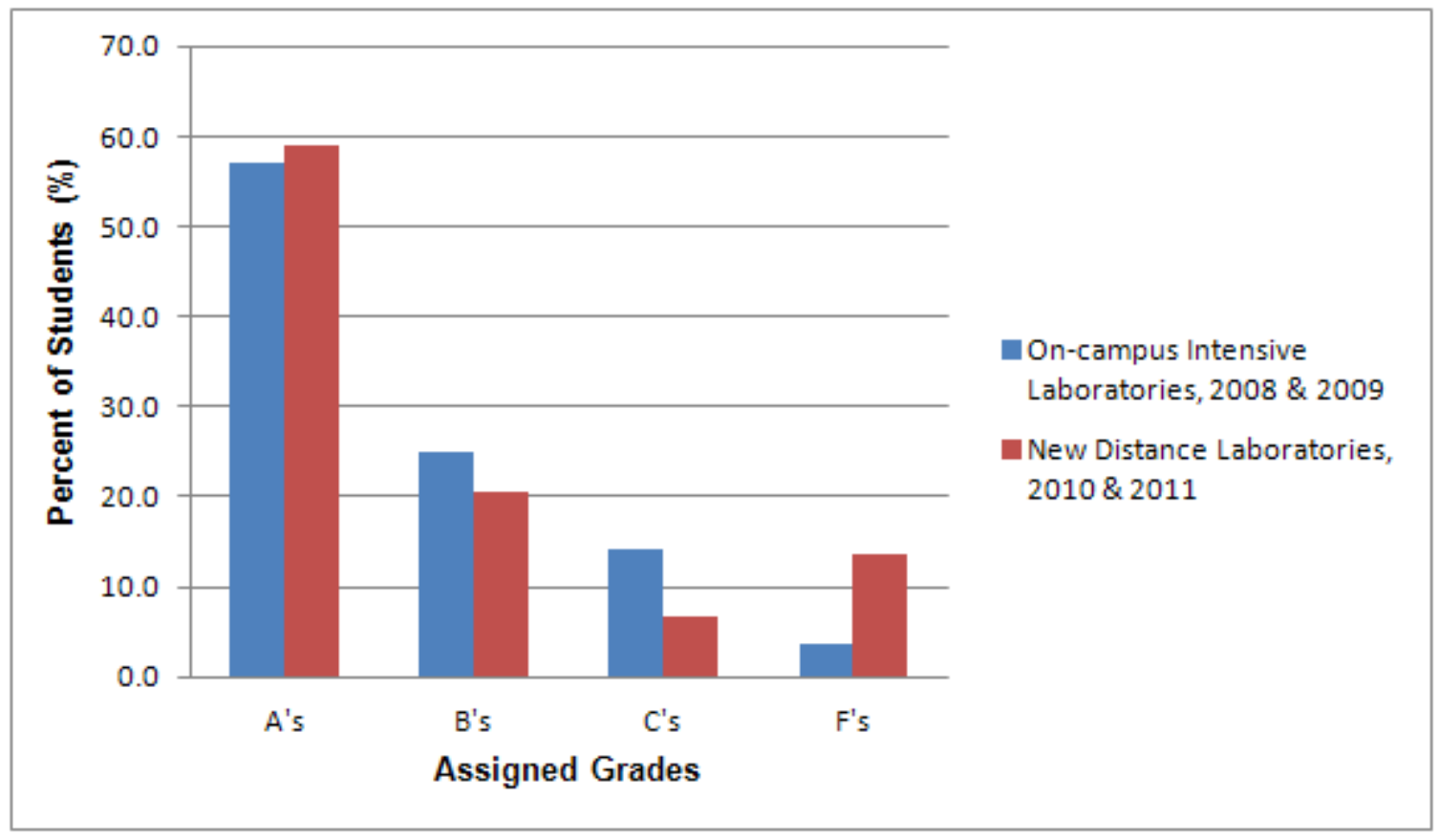

Figure 2. Percentage of students achieving each grade range via the two modes of delivery; on-campus, intensive laboratories in 2008 and 2009, and new, blended, distance laboratories in 2010 and 2011. Assigned grades include all sub-divisions within; for example, A's include A-, A, and A+letter grades. F grades include those that did not complete or failed the course, but do not include withdrawals.

One key goal of this project was to ensure the newly developed distance laboratory courses would be accepted for credit by other academic institutions in our province of British Columbia (BC). In BC, course transfer credit is facilitated by a provincial articulation system directed by the provincial government (British Columbia Council on Admissions and Transfer [BCCAT], 2012a). Chemistry representatives from all the other provincial post-secondary institutions were presented our approach to first year, general chemistry distance laboratories, and once the new, blended, distance lab course offerings were launched in 2009, course outlines were sent to all receiving institutions in $\mathrm{BC}$ with a request for course transfer credit. Review by chemistry educators at each receiving institution resulted in both new courses being accepted for transfer credit at all other educational institutions throughout the province (BCCAT, 2012b). These distance laboratory courses, together with the appropriate first year general chemistry lecture courses, satisfy course prerequisites for admission into second year chemistry 
courses. This transfer credit acceptance is significant to our students and a validation of the equivalency, quality, and rigour of the new, blended, distance laboratories.

Finally, we feel those students that successfully completed the new distance lab courses were well prepared when they continued on to second year chemistry courses at our own institution. Future plans include the careful quantitative and qualitative tracking of the distance laboratory students to document their skills and knowledge performance in subsequent chemistry laboratory courses and contribute evidence-based analysis to this continuing conversation.

\section{Conclusions}

It is possible to provide distance learners with authentic and meaningful laboratory experiences that satisfy Bachelor of Science program requirements, are accepted for transfer credit by other academic institutions, and offer valid alternate delivery modes. At Thompson Rivers University, two blended, distance general chemistry laboratory courses were developed using a constructive alignment process linking learning outcomes to pertinent assessment strategies. Developing home experimental kits for extensive, hands-on work and online educational resources including videos, course management, and assessment allows our distance chemistry students the open access and flexibility of at-home learning. When compared to our previous intensive oncampus laboratory courses, these new distance laboratory courses have somewhat lower completion rates, have comparable final grades and laboratory competencies, and have been extremely popular with increased student enrolments. By incorporating laboratory reports, safety quizzes, reflective journaling, digital photo documentation, and invigilated written and online practical exams into the student assessment scheme, these laboratory courses provide thorough evaluation of the learner, necessary for first year general chemistry transfer credit and acceptance by other post-secondary educational institutions. Overall, this was a very successful endeavour and we plan to continue with a detailed qualitative and quantitative assessment of these courses and the student learning experience. 


\section{References}

Al-Shamali, F., \& Connors, M. (2010). Low-cost physics home laboratory. In D.

Kennepohl \& L. Shaw (Eds.), Accessible elements: Teaching science online and at a distance (pp. 131-145). Edmonton, AB: AU Press.

Bennett, S. W., Seery, M. K., \& Sövegjarto-Wigbers, D. (2009). Practical work in higher level chemistry education. In I. Eilks \& B. Byers (Eds.), Innovative methods of teaching and learning chemistry in higher education (pp. 85-102). Cambridge, UK: RSC Publishing.

Benson, A. (2004). Distance education: Ready and willing to serve the underserved? Quarterly Review of Distance Education, 5(1), 51-57. Retrieved from http:/ / www.infoagepub.com/index.php?id=89\&i=154

Biggs, J . (2003). Teaching for quality learning at university (2nd ed.). Maidenhead, Berkshire, UK: Open University Press.

Boschmann, E. (2003). Teaching chemistry via distance education. J ournal of Chemical Education, 80(6), 704-708. doi:10.1021/ed080p704

Bradley, J . D., Durbach, S., Bell, B., Mungarulire, J., \& Kimel, H. (1998). Hands-on practical chemistry for all-Why and how? J ournal of Chemical Education, 75(11), 1406-1409. doi:10.1021/ ed075p1406

British Columbia Council on Admissions and Transfer. (2012a). How to articulate handbook - Requesting and assessing credit in the BC transfer system. Retrieved from http:// www.bccat.ca/articulation/resources/handbook/

British Columbia Council on Admissions and Transfer. (2012b). Search results for TRUOL sending courses CHEM 1505 and CHEM 1525 transfer. Retrieved from http:// www.bctransferguide.ca/ search/ by-sender/

Brouwer, N., \& McDonnell, C. (2009). Online support and online assessment for teaching and learning chemistry. In I. Eilks \& B. Byers (Eds.), Innovative methods of teaching and learning chemistry in higher education (pp. 123-152). Cambridge, UK: RSC Publishing.

Buntine, M. A., Read, J. R., Barrie, S. C., Bucat, R. B., Crisp, G. T.; George, A.V., .., \& Kamble, S. H. (2007). Advancing chemistry by enhancing learning in the laboratory (ACELL): A model for providing professional and personal development and facilitating improved student laboratory learning outcomes. Chemistry Education Research and Practice, 8(2), 232-254.

doi:10.1039/B6RP90033J 
Busstra, M. C., Hulshof, P. J . M., Houwen, J ., Elburg, L., \& Hollman, P. C. H. (2012). Nutrient analysis explained for non-chemists by using interactive e-learning material. J ournal of Food Composition and Analysis, 25(1), 88-95. doi:10.1016/j.jfca.2011.07.003

Carr, S. (2000). As distance education comes of age, the challenge is keeping the students. The Chronicle of Higher Education, 46(23), A39-A41. Retrieved from http:/ / chronicle.com/article/ As-Distance-Education-Comes-of/ 14334/

Casanova, R. S., Civelli, J . L., Kimbrough, D. R., Heath, B. P., \& Reeves, J . H. (2006). Distance learning: A viable alternative to the conventional lecture-lab format in general chemistry. J ournal of Chemical Education, 83(3), 501-507. doi:10.1021/ ed083p501

Coryell, J . E., \& Chlup, D. T. (2007). Implementing e-learning components with adult English language learners: Vital factors and lessons learned. Computer Assisted Language Learning, 20(3), 263-278. doi:10.1080/09588220701489333

Domin, D. S. (1999). A content analysis of general chemistry laboratory manuals for evidence of higher-order cognitive tasks. J ournal of Chemical Education, 76(1), 109-111. doi:10.1021/ ed076p109

Downing, K. F., \& Holtz, J . K. (2008). Online science learning: Best practices and technologies. Hershey, PA: IGI Global.

Elliott, M. J ., Stewart, K. K., \&Lagowski, J . . (2008). The role of the laboratory in chemistry instruction. J ournal of Chemical Education, 85(1), 145-149. doi:10.1021/ ed085p145

Forinash, K., \&Wisman, R. (2001). The viability of distance education science laboratories. T.H.E. J ournal, 29(2), 8-13. Retrieved from http://thejournal.com/Articles/2001/09/01/The-Viability-of-DistanceEducation-Science-Laboratories.aspx

Harasim, L. (2000). Shift happens: Online education as a new paradigm in learning. The Internet and Higher Education, 3(1-2), 41-61. doi:10.1016/ S10967516(00)00032-4

Harasim, L. (2011). Learning theory and online technologies. NewYork: Routledge Press.

Heinze, A., Procter, C., \& Scott, B. (2007). Use of conversation theory to underpin blended learning. International J ournal of Teaching and Case Studies, 1(1/2), 108-120. doi:10.1504/ IJ TCS.2007.014213 
Holmberg, B. (1989). Theory and practice of distance education. London: Routledge Press.

Howell, S. L., Laws, R. D., \& Lindsay, N. K. (2004). Reevaluating course completion in distance education: Avoiding the comparison between apples and oranges. Quarterly Review of Distance Education, 5(4), 243-252. Retrieved from http:/ / www.infoagepub.com/index.php?id=89\&i=154

J ackson, M. D. (1998). A distance-education chemistry course for nonmajors. J ournal of Science Education and Technology, 7(2), 163-170. doi:10.1023/ A: 1022516624477

J eschofnig, L., \&J eschofnig, P. (2011). Teaching lab science courses online: Resources for best practices, tools, and technology. San Francisco: J ossey-Bass.

Karadeniz, S. (2009). Flexible design for the future of distance learning. Procedia Social and Behavioral Sciences, 1(1), 358-363. doi:10.1016/j.sbspro.2009.01.066

Kennepohl, D. (2007). Using home-laboratory kits to teach general chemistry. Chemistry Education Research and Practice, 8(3), 337-346. doi:10.1039/b7rp90008b

Larreamendy-J oerns, J ., \& Leinhardt, G. (2006). Going the distance with online education. Review of Educational Research, 76(4), 567-605.

doi:10.3102/ 00346543076004567

Lim, D. H., \& Morris, M. L. (2009). Learner and instructional factors influencing learning outcomes within a blended learning environment. Educational Technology \& Society, 12(4), 282-293. Retrieved from http:// www.ifets.info/journals/ 12 4/24.pdf

Lyall, R., \& Patti, A. F. (2010). Taking the chemistry experience home - Home experiments or "Kitchen Chemistry". In D. Kennepohl \&L. Shaw (Eds.), Accessible elements: Teaching science online and at a distance (pp. 83-108). Edmonton, AB: AU Press.

Ma, J ., \& Nickerson, J . V. (2006). Hands-on, simulated, and remote laboratories: A comparative literature review. ACM Computing Surveys, 38(3), Article 7, 1-24. doi:10.1145/ 1132960.1132961

Macaulay, J . O., Van Damme, M.-P., \&Walker, K. Z. (2009). The use of contextual learning to teach biochemistry to dietetic students. Biochemistry and Molecular Biology Education, 37(3), 137-143. doi:10.1002/ bmb.20283 
MacLean, P., \& Scott, B. (2011). Competencies for learning design: A review of the literature and a proposed framework. British J ournal of Educational Technology, 42(4), 557-572. doi:10.1111/j.1467-8535.2010.01090.x

Mawn, M., Carrico, P., Charuk, K., Stote, K., \&Lawrence, B. (2011). Hands-on and online: Scientific explorations through distance learning. Open Learning, 26(2), 135-146. doi:10.1080/ 02680513.2011.567464

Mayadas, A. F., Bourne, J ., \& Bacsich, P. (2009). Online education today. Science, 323(J anuary), 85-89. doi:10.1126/ science.1168874

Moore, J . L., Dickson-Deane, C., \&Galyen, K. (2011). E-learning, online learning, and distance learning environments: Are they the same? Internet and Higher Education, 14(2), 129-135. doi:10.1016/j.iheduc.2010.10.001

Oblinger, D. G., \& Hawkins, B. L. (2005). The myth about e-learning. Educause Review, J uly/ August, 14-15. Retrieved from http:// net.educause.edu/ir/ library/pdf/ ERM05411.pdf

Osguthorpe, R. T., \& Graham, C. R. (2003). Blended learning environments: Definitions and directions. Quarterly Review of Distance Education, 4(3), 227-233. Retrieved from http:// www.infoagepub.com/index.php?id=89\&i=154

Picciano, A. G., \& Dziuban, C. D. (Eds.). (2007). Blended learning: Research perspectives. Sloan-C. Retrieved from http:// sloanconsortium.org/node/ 921

Pickering, M. (1993). The teaching laboratory through history. J ournal of Chemical Education, 70(9), 699-700. doi:10.1021/ ed070p699

Reeves, J ., \& Kimbrough, D. (2004). Solving the laboratory dilemma in distance learning general chemistry. J ournal of Asynchronous Learning Networks, 8(3), 47-51. Retrieved from http:// sloanconsortium.org/jaln/v8n3/ solvinglaboratory-dilemma-distance-learning-general-chemistry

Reid, N., \& Shah, I. (2007). The role of laboratory work in university chemistry. Chemistry Education Research and Practice, 8(2), 172-185. doi:10.1039/ b5rp90026c

Sangrà, A., Vlachopoulos, D., \& Cabrera, N. (2012). Building an inclusive definition of elearning: An approach to the conceptual framework. The International Review of Research in Open and Distance Learning, 13(2), 145-159. Retrieved from http:/ / www.irrodl.org/index.php/irrodl/article/ view/ 1161

Schlosser, L. A., \& Simonson, M. R. (2010). Distance education: Definition and glossary of terms ( $3^{\text {rd }}$ ed.). Charlotte, NC: Information Age Publishing. 
Talanquer, V. (2012). Chemistry education: Ten dichotomies we live by. J ournal of Chemical Education, 89(11), 1340-1344. doi:10.1021/ ed300150r

Thompson Rivers University Act. (2005). Province of British Columbia, Queen's Printer. Retrieved

from http:// www.bclaws.ca/ EPLibraries/bclaws new/ document/ID/freeside/ 0 $\underline{0 \quad 0501701}$

TRU Institutional Planning and Analysis (IPA). (2012). Fiscal year 2011-2012 factbook. Retrieved from http:// www.tru.ca/_shared/assets/11-12_Factbook26443.pdf

Watson, J., Murin, A., Vashaw, L., Gemin, B., \& Rapp, C. (2012). Keeping pace with K12 online learning. Evergreen Education Group. Retrieved from http://kpk12.com/reports/graphics/

Wiggins, G. P., \& McTighe, J . (2005). Understanding by design (2 $2^{\text {nd }}$ ed.). Alexandria, VA: Association for Supervision and Curriculum Development.

Williams, N. A., Bland, W., \&Christie, G. (2008). Improving student achievement and satisfaction by adopting a blended learning approach to inorganic chemistry. Chemistry Education Research and Practice, 9(1), 43-50.

doi:10.1039/b801290n

Wu, J .-H., Tennyson, R. D., \&Hsia, T.-L. (2010). A study of student satisfaction in a blended e-learning system environment. Computers \& Education, 55(1), 155164. doi:10.1016/j.compedu.2009.12.012

\section{Athabasca University $\mathbf{a}$}

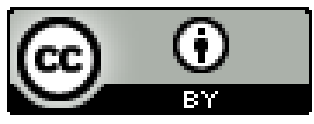

